\title{
FLORENSKY AND HEIDEGGER: CONCENTRATION OF THINKING STRATEGIES
}

\section{Stepan Vozniak}

\section{INTRODUCTION}

Philosophy is inherently harmonious and proportionate, and these are not just lofty epithets designed to give praise, but rather an essential indication of the content and direction of philosophy. The fundamental integrity of the world is the first condition for the emergence and implementation of thought as such. And it is no coincidence that the ancient Greek myth and logo as the first versions of the discourse about the world manifest themselves in the form of art - while their aesthetic characteristics and ontological nature coincide. Thinking and judgment go hand in hand with delight, chanting, praise. Therefore, $\varphi 1 \lambda 0 \sigma 0 \varphi 1 \alpha$ is love of wisdom, not just wisdom. Moreover, $\varphi 1 \lambda 1 \alpha$ in this case is what precedes, makes possible and gives rise to бopı $\alpha$. Admiration, surprise and the ability to enjoy the mysterious beauty of the integrity of the world give rise to desire to conceive this integrity.

The fact of the existence of the history of thinking reveals historicity as one of the basic characteristics of thinking. Thinking is thinking only when it knows and remembers itself in its formation. Thus, the indicated rhythm, according to which thinking is consonant with being, is grasped as a memory and this is the first thing to be noted. Secondly, the presence of all kinds of concepts, systems, directions and traditions allows us to raise the question of the essence of thinking from different points, which makes understanding the problem voluminous, lively and meaningful. The history of philosophy makes it possible to compare initially disparate views - and in finding common ground to identify some ontological parameters of the desired problem - those that cannot be seen from a one-dimensional position.

One of the characteristic features of the modern world is the mixing of various traditions, while it is important to note that quite often this is not an eclectic mixture, but the inner kinship of various traditions. This text is an attempt to hear in the ideas of Martin Heidegger and Pavel Florensky a certain consonance with respect to memory as a gathering foundation and creative content of thinking. Within the framework of the problem of thinking, both philosophers are extremely interesting in that, as thinkers belonging to the twentieth century, they refer us to two traditions fundamental to European culture and philosophy: Martin Heidegger - to the event of ancient Greek thought, Pavel Florensky - to the event of Christian revelation. At the same 
time, the way of organizing their thoughts causes directly opposite characteristics - from admiration and pointing to radical novelty to recognizing their thoughts in such a way that violates the logical harmony and adequacy $^{1}$.

\section{Memory as the gathering foundation of thinking in Heidegger's concept}

When addressing the problems of thinking in Heidegger's philosophy, one should constantly not lose sight of two points. Firstly, Heidegger makes an ontological distinction between calculus thinking, characteristic of science and directed towards the essence, and substantive thinking, directed towards being. Secondly, one should not look for the essence of thinking in the ways of anthropology: thinking is not a certain property of a person, it does not belong to him at all - a person is able to enter into it.

The memory is most articulated problematized in the lecture course of 1951-1952, "What is called thinking?". But before turning to this text, I would like to draw attention to the most famous work of the philosopher "Being and Time". In the text of "Being and Time" there is no reflexive explication of the relationship between memory and thinking. But this indicates on the necessity to take into account the initial focus thoughts on time as a way of being Dasein: time is the only way of existential going out of the Dasein to its own existence. In this formulation of the question, the memory problem is invisibly present - both in terms of understanding the temporality of both the universal historicity of being, and in terms of the "personality" - existential self-determination of Dasein as subjectivity in its being through time. When referring to existential analytics of Dasein, memory could be considered as one of the defining existentials along with fear, care, determination, being-to-death, guilt, conscience. But the memory is not an existential in the same sense that and the above-mentioned fear, caring, conscience, guilt, etc. The fact is that in this case we call existentials the points of the most intense experience of a person meeting as a kind of essence with being. Memory is not an experience; in the case of understanding time as the only way in which being has been given, memory is rather the subjective basis of this given. In other words, in "Being and Time", memory is not that of time, it is how Dasein times itself, intentionally "tuning in" to existentials. In some sense, here you can hear an echo of the psychological understanding of memory as a property of consciousness to combine different temporal

\footnotetext{
${ }^{1}$ Гальцева Р. А. Мысль как воля и представление (Утопия и идеология в философском сознании П. А. Флоренского). П.А. Флоренский: pro et contra / Сост., вступ. ст., примеч. и библиогр. К. Г. Исупов. СПб.: РХГИ, 1996. С. 573-579, 597.
} 
modes in one relevant representation. Thus, the memory in "Being and time" can be defined as some existential schematics of temporality.

In the lecture course "What is called thinking?" The understanding of memory is rather explicit. It's logically to expect that the name is preceded by a logical-methodological study of the nature of thought, which creates a new conceptual system or even a new discursive definition of what is thought. But the main leitmotif seen in this text is completely different. This is the constant escape of the being of thinking from man. Something is calling us to think, but it can only be something that has not been thought: "Most thought provoking in our thought - provoking time is that we are still not thinking"2. And the point is not only and not so much that we have not yet found the true object to be thought, or have not learned to think correctly. The case in fact, that is, that truly requires understanding, constantly slipping away from our thinking : "We Said: man to still does not think, and this because what must be thought about turns away from him; by no means only because man does not sufficiently reach out and turn to what is to be thought" ${ }^{\text {. }}$. Why is slipping away? What is missing - visual acuity, depth of knowledge, or physiological capabilities? Nothing of the kind, turns away, pulls away, slips away that which is given for thought. Consequently, we are not able to grasp, pull, turn to ourselves this given - we do not own and do not control thinking.

A person falls into thinking; this is some initial situation into which he is thrown, and the conditions of this situation are by no means dictated by the person himself. Without a doubt, thinking is a human matter, and the most important thing, but we in no way control the way of thinking and being that is given to us. The only possible way of interacting with essence and being for a person is precisely thinking, but it does not grow out of a person, but out of being, from his way of organizing. We are not able to change the laws of logic since these laws stem from the way the universe is created, we are not able to change the temporal way of our being as well. We can only prevent it before the due date. It is not possession of thinking in principle, and perhaps it is the greatest gift to man - because it is through this not possession that we are given the opportunity to transgress, to walk, to extirpate into thinking as the Other to ourselves, thereby filling the original ontological for us with meaning that, again, it is not created by us, but is seen in being.

Does this mean that we are not able to think at all? In no way. Because it is not we own thinking, but thinking owns us: Heidegger emphasizes reciprocity movement - " $\ldots$ we truly incline only toward something that in turn inclines toward us, toward our essential being, by appealing to our essential being as

\footnotetext{
${ }^{2}$ Heidegger M. What is called thinking? Ed. J. Glenn Gray. Of Harper Perennial, 1976. P. 6.

${ }^{3}$ Heidegger M. What is called thinking? Ed. J. Glenn Gray. Of Harper Perennial, 1976. P. 8.
} 
the keeper who holds us in our essential being. What keeps us in our essential nature holds us only so long, however, as we for our part keep holding on to what holds us. And we keep holding on to it by not letting it out of our memory. Memory is the gathering of thought. Thought of what? Thought of what holds us, in that we give it thought precisely because It remains what must be thought about" ". Memory is that which holds us in our being, in what we are. Preservation of integrity assumes that this integrity already existed from the beginning, and in the loss of it, is assembled again. Consequently, memory is also the gathering, unification and preservation of our essence in the literal sense of "safe and sound".

So, according to Heidegger, what do we keep in mind? First of all, ourselves, in every sense, starting with the psychological and ending with the ontological. We preserve ourselves as subjectivity, atomic in terms of inseparability, whole unity, understood as a person - and as a result of this, we preserve ourselves as a human race, literally "remember who we are". But we also store what is given for thought - in this way we store the being in its being. In other words, we keep the world in a memorable preservation. And mindfulness in this case is thought of as a force, a connecting thought, thinkers and conceivable in integrity.

That is why oblivion of being causes fear: it turns out that oblivion is termination from storage, abandonment of the stored to its fate. And if the main subject of the mindset from storage is a holistic connection of thinking and being, then it turns out that in communication this connection is lost.

It was previously mentioned that Heidegger thinks that this is thought to be elusive, turning away from us. Such a definition contains a very significant indication: it is only through slipping away, hiding the conceivable from us that we are able to realize, feel its ontological significance and materiality in order to preserve ourselves and the world. The same can be said about memory as a preserving thoughtfulness of thinking: in oblivion, in the loss of this repository, we comprehend its necessity and fundamentality.

What do we forget in oblivion of being? At the individual level, oblivion, forgetting oneself is always the loss of some personal integrity. We are what we are only when we remember ourselves - that is, we realize what exactly forms the center of our personality. Forgetting inevitably means some decay, the inferiority of our wholeness. Very clearly evidenced by the various types of mental disorders, which are ontological level and are characterized by oblivion. For example, the partial loss of some of the conscious perceptions and guidelines again leads to partial disorders, syndromes and pathologies. Amnesia as a complete and absolute forgetting of all persistent and significant

\footnotetext{
${ }^{4}$ Heidegger M. What is called thinking? Ed. J. Glenn Gray. Harper Perennial, 1976. P. 3-4.
} 
ideas is an irreversible disintegration of the personality, strictly speaking death, although not physiological. Thus, memory is understood not only as a separate ability of the psyche, but as the force that holds in agreement, awareness and integrity all the diverse forces, impulses and aspirations of consciousness.

And what about the oblivion of being at the universal historical level? What is lost in this case? First of all, the unity and continuity of the transfer of historical experience. Metaphorically speaking, we are losing our "roots" in the oblivion of being. Both historical and worldview. Going back to the roots is a very important intonation of Heidegger's philosophy. Any soil cultivation - both personally determined (as in the case of Heidegger's views), and socio-historical (the general attitude that took place in Germany between the two world wars) - is nothing more than an attempt to overcome the inevitably growing oblivion of being. But the most interesting and at the same time tragic is that this attempt doomed to failure in advance. This is because, with the loss of memory, understood as the oblivion of being, we forget not only our historical and temporal nature, but also our ontologically timeless essence. This is very clearly seen in the example of worldview crises characteristic of the modern socio-historical situation. Any loud-sounding (and therefore, according to Heidegger, inauthentic) calls to recall one's historical, temporal meaning - back to soil, to the authentic historical spirit of our community, to blood, to national or ethnic foundations - inevitably leads to the fact that we no longer define our own being, but those meanings determine $u s$, and it is precisely these fateful entities (blood, elements, spirit, nation, ethnos, party) which are engaged in this, whose historical guises have already shown themselves to be something monstrous. In an effort to regain lost memory, we surrender ourselves to the "spirit of the times", the "harsh demands of our time", often even simply to "the realities of life", or vice versa, we strive back to "historical memory" or fight to restore "historical truth and just rain", without thinking who and what will dictate to us in this blind, thoughtless, thoughtless fidelity and struggle. Memory preserves our being not only in history, in temporality, which reveals our being to us. It also protects a person's ability to resist his time and his own integration, subordination to the existing and dominant being. Returning to the source, the memory keeps what is conceivable for thinking. Memory is the guardian of the limit of being and non-being, protecting a human being from falling into a complete absence of thought.

Let us pay attention to the symphonic sound of thought and being. Memory as rhythm, harmony-forming force - preserves the symphony of the sound of thought, existing and sounding-about. For the loss of being, it always brings disunity, harmony, dissonance, since the binding bases of symphony 
are lost. Symphony is being replaced by cacophony - especially vividly, familiarly and vividly, again, this is illustrated by the crisis periods of the existence of any socio-historical formation. In yet another such oblivion, the field of thinking explodes in a cacophonic, disordered, and painful abundance of all kinds of false prophets, pseudoscience, charlatan religious practices, false ideological systems, and political ideologies. Instead of sounding-aboutbeing, a thought begins to scream about it in a bad voice. Simply put, in such periods "uniform craziness" starts (you can add - not only "uniform", but also "essential"): demention, distortion, dispersal of what must remain in the assembled unity. The oblivion of being, the loss of a saving and gathering memory inevitably leads to the loss of reason and thought, and now truly, "a dream of reason gives birth to monsters". Memory is the guardian of what is the edge of man, and man should not stand up for this edge.

Is, according to Heidegger, oblivion of being inevitable, or is it just some local distortion, the descent from the true path, which might not have been? Unfortunately, not. We still do not think, not because we are not addressing the given for thought enough - it draws itself away, eludes us. Repeatedly addressed Heidegger's philosophy sounded accusations of gloomy-mock tragedy and deliberate, excessive dramatization of the fate and place of man in life. Indeed, according to Heidegger, a human being is determined by the fact that it is burdened by its own being and constantly strives from it into oblivion, in the loss of memory. Actually, when we say that the essence of thinking does not belong to us, that we do not own it, we affirm that we can think only from a lack, from a lumen, from our human nothingness. This is the flip side of the comprehensive harmony of thought and being - they are identical and correlated in their essence, but they are not an indistinguishable continuity. The reverse side of any inseparable unity is its lack of fusion, and the thinking that falls upon us as a gift of our being thrown into being is thinking from a gap, from a split human being (here it is impossible not to recall the Hegelian "unfortunate consciousness").

Summing up what was said about Heidegger's understanding of the relationship between memory and thinking, we should return to the text of the lecture course "What is called thinking?". And note one more point that is significant for what follows. Thinking stores in memory what is given for thought. This for thought should be understood as a certain gift, descent only then thinking is actually thinking. The response of thinking to this gift of the conceivable is gratitude, therefore, thinking in its mindful being is gratitude. In the text, Martin Heidegger surprisingly strengthens and roots this turn of thought in the linguistic features of the German language: thinking (Denken), memory (Gedanc) and gratitude (Dankbarkeit) are the same root 
words. The saying in the language sounds in being, therefore, the kinship of thinking and memory is from the beginning.

It was previously indicated that the descent from memory, mind, loss of collected thinking unity and wholeness leads to distortion, distortion, separation of what is initially and essentially thought to be necessary to be collected. Keeping the direction of the indicated thought "in mind", we turn to the consideration of the understanding of memory in the light of the ideas of Pavel Alexandrovich Florensky.

\section{Memory as the basis of eternal life in the concept of Florensky}

Pavel Florensky is a Christian thinker, Orthodox priest, religious philosopher, and the essential center of his ideas is Christian revelation. An amazing combination of quiet, focused depth of peering with liveliness and richness of the sounding discourse is striking, which immediately catches your eye when accessing its texts. In general, religious philosophy, thinking as if "inside" Christian tradition, has a very important advantage: in it the unfolding thought is initially, originally, a priori rooted in being, from the very beginning of its development it is permeated with the light of Divine wholeness and validity - and, most interestingly, such rootedness does not destroy the internal discursiveness, dynamism and reflexivity, the "philosophical" nature of thought. There is some initial remembrance, storage, saving of thought - and saving is something with which it brings itself into a humble agreement even before the start of its own movement. In this case, the service of philosophy to the truth of Christian revelation in accordance with theology is understood not as submission and infringement of philosophical "free thinking", but as a foundation that justifies and raises thought to unprecedented heights.

The central work of Pavel Florensky is his master's thesis, "The Pillar and Affirmation of Truth. The Experience of the Orthodox Theodicy in the Twelve Letters". For further research, the epigraph of the whole work is extremely important: these are the words of Gregory of Nyssa " ' $\eta \delta \varepsilon \gamma v 0 \sigma 1 \zeta$

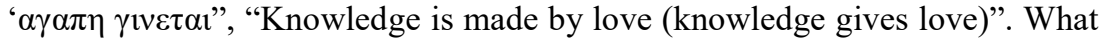
is important here? Cognition is made through love; cognition is transformed into love. Love acts both as what makes knowledge possible, and as its highest goal. In Christianity, there is some amazing ontological vigilance and sensitivity, able to catch, perceive, accept and conceive the coincidence and essential interpenetration of the absolute rationality of the Divine with its absolute love, which was already among the Greeks, but was strengthened in the Christian consciousness. No matter how we explain love, its original meaning, the "phenomenological framework" will be unchanged: the complete conversion of one to the other, the transfer of one's own essential center to something Other, which is understood as more substantial than 
myself. The aspect ratio loving and mind hides something very significant - is a reason itself only when is in harmony with the universal, universal (divine?). Consonant wholeness, or holistic agreement with the Absolute, is the only guarantee of the rationality of thought, since it is in such a loving agreement that the foundation is found. Reason without love is already a reason, which is understood not as wholeness, but as a self. It is love that overcomes the fear of losing one's self and allows the universal not to crush, wipe, obscure the individual, but on the contrary - to reveal the individual in its ontological uniqueness and significance. A self that is afraid of dissolving in the absolute is doomed to decay, dissolving in itself, since self-conversion is incapable of revealing its own essence. In the rational self-will and desire to explain everything only through oneself, one's own limits of individuality are lost, fogged and blurred, and then it is inevitably doomed to the loss of oneself.

Reason is always loving co-thought, harmony, co-being, co-sound. Therefore, the love of wisdom is reasonable. But wisdom without love is rational. Philosophy is therefore the love of wisdom, because it can overcome the pride of possessing wisdom. The universal is conceived of as holistic, intact by violent separation, tearing into separate individuals. The rational self is therefore the self because it wants to be itself. Its destiny is demons, who besiege the integrity of harmony and harmony with the universal and Divine: in the literal sense, "aimlessness" and "godlessness", which Florensky recognizes as sin.

And it is on the way that Florensky reveals the true nature of sin that we gain his understanding of the essence of memory. Here we should recall two points that have already sounded above. Firstly, this is an indication that the loss of mind, loss of sonority, memory and integrity is a distortion, perversion of the originally intact, preserved. Secondly, we must remember that the thematic field of the work of Pavel Alexandrovich is the problem of theodicy. Therefore, the question gains strength and sounding how in the world created by the all-good and absolute Deity, the sinfulness, distortion, perversity indicated above - in other words, evil - can be present? Florensky speaks of two paths: one of them is the path to the Truth, but how can there be another path that does not resemble it, if the Truth is the source of all existence, and there is nothing outside the Truth? How is it possible to admit some NonTruth, some Falsehood? If God is Life and the Culprit of life, then Falsehood is Death and the source of death, i.e. destruction. God is Harmony and Order; and Lies are Disorder and Anarchy. God is Holiness; and Lies are Sinfulness. But how can there be sinfulness? The logic of us leads to the fact that, although there is sinfulness, it is non-existent ${ }^{5}$.

\footnotetext{
${ }^{5}$ Флоренский П. А. Столп и утверждение истины. (Том 1, часть 1. Том 1, часть 2). М.: Правда, 1990. С. 167-168.
} 
What kind of being is the sins of reality, which is "non-existent"? What is the status of lies and death if they are non-being? Is it possible to conceive them in their being if their being as such is not? Not to recall the same Parmenides, it is wise to beware us of his, long before ours, time: " $<\ldots>$ being because there are, and there is nothing there, I pray thee think it over. First I turn you away from this path of search $<\ldots>$ So I will not allow I to say or think: it is unthinkable, inexpressible There is, which is not"6. A caution is more than appropriate - a thought is only then able to hold on, to keep itself intact when it refrains from an empty place, non-being, and is directed at the existing, becoming a thought-about, and not a thought-aboutnothing. Calling non-being, calling it into thought, we thereby can lose the thought. The ancient Greeks very vividly, albeit non-reflexively, felt the whole horror of the empty, evil infinity of non-being.

Nevertheless, there is sin. Moreover, it is so close to us that sometimes seems that there is nothing but him. It is so powerful in this world that he obscures its own light of True Being. How can non-being condone Being? What is the power of Lies, which is sin? It is that she impersonates the Truth. Sinfulness is a non-existence, deceitfully pretending to be true and justified. Sin is a fake, a deceit, a simulation of what really exists. What does deception do, does it create something essentially and ontologically new, belonging to being? No, there is no increase in being in sinful deception - but the really existing one undergoes distortion, distortion, perversion, what is created in Hegelian and Marxist philosophy, we call the transformed form of reality, which is non-substantial, but replaces the true form.

Here is the power and power of sin, since it is much easier to pervert and destroy the whole and intact than to create or restore, repair the wholeness. What is the destruction of the whole leading to? To its disintegration into parts, to plurality, which does not have some ontological unity. When we say that a certain thing is broken, damaged, we mean that some of its structural elements cease to functionally interact with each other, violate the integrity of the thing, which should be greater than the sum of its elements. Sin decomposes the whole into a plural, fragmented, but at the same time diverse variety of different variants of distortions of the real. Therefore, in that reality, which is our nearest life world, in this world evil acquires such a colossal, colorful and often enticing abundance of forms. Therefore, "his name is the legion". Demons always there are lots of, but they are always precipitated by one and the same fortress.

But is it possible that just the communication of the truly holistic to the multiply false can create, create something fundamentally new? No way.

\footnotetext{
${ }^{6}$ Фрагменты ранних греческих философов. Ч. 1. М.: Наука, 1989. С. 296-297.
} 
Why? Because any single form, being a product of that very sinful decay, does not strive for the integrity of something more than it, but only for itself. The sinfulness of individuality is in self-will. This is precisely the aforementioned self, desiring self-affirmation, volitioning only and exclusively itself. And in this self-will, self-affirmation, the main weakness of any evil and any sin is: "Desiring only himself, in his "here" and "now", the evil self-affirmation is inhospitablely locked away from everything that is not it; but, striving for a self-deity, it doesn't even remain similar to itself and crumbles and decomposes and crumbles in the internal struggle"7 .

Ontologically, sin is a deception, a falsification of being. What is $\sin$ anthropologically? What is sin that has taken possession of man, his soul? Pavel Florensky defines it this way: "Sin is the moment of discord, disintegration and collapse of spiritual life. The soul loses its substantial unity, loses consciousness of its creative nature, is lost in the chaotic whirlwind of its own states, ceasing to be their substance. I choke in the "mental flood" of passions" ${ }^{\text {. }}$. And here is already a clear harmonious, symphonic consonance with the idea of Heidegger: in the oblivion of being, we forget ourselves, because with the loss of memory, that which stores us in our essence is lost, destroyed.

But what, following Christian tradition, keeps us and what is lost in a sinful fall? First of all, what is holding us in a single, inseparable integrity is lost. Where is the hidden center of our existence? In the Other to us, in the Divine. What can connect us with the Other, understood as the Divine? Love: "Without love - and love needs above all the love of God - the personality disintegrates in the granularity of the psychological elements and moments. The love of God is the connection of personality" ${ }^{\prime \prime}$. Love still presents itself as the power of binding. That is why thought is capable of moving from one to another, from the individual to the universal and from the general to the one, which connects these "one", "another", "general", "unit" with some universal connection. Here again sounds loving knowledge, philosophy. And what, then, is sin for reason? How does he harm him? The answer to this question is also found in Pavel Florensky: "Sin is that which deprives the possibility of justification and, therefore, explanatio, ie rationality. In the pursuit of sinful rationalism, consciousness loses its intrinsic

${ }^{7}$ Флоренский П. А. Столп и утверждение истины. (Том 1, часть 1. Том 1, часть 2). М.: Правда, 1990. С. 171.

${ }^{8}$ Флоренский П. А. Столп и утверждение истины. (Том 1, часть 1. Том 1, часть 2). М.: Правда, 1990. С. 174.

${ }^{9}$ Флоренский П. А. Столп и утверждение истины. (Том 1, часть 1. Том 1, часть 2). М.: Правда, 1990. С. 174. 
rationality" 10 . The proud, self-conscious rationality of the love of wisdom turns into the lust of reason.

So philosophy, the destiny of which is to look out for the one and the essential in existential diversity, turns into an ideology, for which the main thing is to create from the essential a ready-made worldview recipe for "value hierarchies", "public orientations", "educational attitudes", which in essence do not serve to explain and understanding of reality, but to ensure the benefit of their own creators. Reason, which has fallen from universal foundation, imagines itself to be reason, always claims to know the last truth of being and, naturally, to how to attach this truth to one's needs.

Here is the second "chord" of the harmony of ideas of Florensky and Heidegger. And oblivion of being, and the fall into sinfulness - lead to the collapse, decay, decay of wholeness and rationality. But in place of the disintegrated mind, the "legion" number of demonic "speculations" always begins to bloom.

What can a man oppose to the overwhelming, all-conquering power of sinful discord and decay? At first, a close, all-round look, there is vanishingly little - chastity and humility. But what is chastity for a gaze refracted in the light of True Being? Let us turn again to the thought of Florensky, who draws attention to the integrity and unspoiled nature of a human being, which a person can lose and forget, but that God always remembers him, he mentions the ritual moment of the Orthodox memorial service - the proclamation of "eternal memory". Thus, we gain an understanding of the essence of memory by Florensky. Destination nost s wisdom held in the world seed of God's memory.

And here it is possible to hear the "third chord" of the harmony of thought of Florensky and Heidegger: memory does not belong to us, it, like thinking, is not our "property", "ability", it is that which is addressed to us as preserving us. And, immediately, the following "refrain": without giving up self-will, which is detachment (Heidegger!) And humble chastity (Florensky!). We fall into the oblivion of being, into the sinful decay of our self.

Earlier we have made a reservation of a principle need for confrontation, resistance time - to be able to preserve our being. Now this idea may sound in a new way: everything in this world is somehow, of course, temporarily, everything is subject to decay and decay. Corruption, decay and death are an inevitable element of the order of things in the world, just as sin and falsehood are inevitable from this world. The world's only one "specific kind of things",

${ }^{10}$ Флоренский П. А. Столп и утверждение истины. (Том 1, часть 1. Том 1, часть 2). М.: Правда, 1990. С. 179. 
contains in its nature, some temporary "vertical" to the Absolute, true being a man. But the timeless, "eternal" essence of man is not given to him immanently, but about five, it is not his property: To counter the corrupting power of time, you must turn to the Other, who keeps us in himself, remembers us: "God grants victory over Time $\left.<_{\ldots}.\right\rangle$ and everything can partake of Eternity. How? - mindful of him" $"$.

The idea of the essence of memory in its sound here grows to unprecedented harmony and inclusiveness: memory is the main ontological foundation and, at the same time, our goal of its presence. All our creative powers, all the best that is capable of being stored in a person, we only turn to one thing - to exist in the world, to cling to some essence, so as not to be swept away and all-consuming stream of time, leave a timeless trace in it, an echo of some higher being, to put it simply, to leave a memory on oneself. Florensky sounds this brilliantly: "Thus $<\ldots>$ and love, and marital fidelity, and parental love for offspring, and all higher activities - in short - all life is based on nothing more than desire, as a thirst for eternal memory"12.

Once again: not we - remember, but - addressed to us (absolute, being, Truth, God) remembers us. But, nevertheless, what is memory "for us", "inside us", how does it manifest itself from within thinking and consciousness? What is the psychological and epistemological dimension of Divine Eternal Memory? Heidegger defines memory as "collected thinking" . In the same "tonality" Florensky also understands memory: "Already its psychological definition, namely, as a natural ability to represent", despite its abstractness, notes its essential connection with thinking processes in general. On the other hand, the theory of cognition, through the concept of transcendental apperception, together with all the latter entering acts of appergenation, reproduction and reconnaissance, makes memory the main cognitive function of the mind"13. Memory collects our diverse ideas into a whole. An amazing property of consciousness is to hold several representations, images, ideas, eidos at once in a single, here-and-nowmoment of time in reflexive awareness and comprehension. Moreover, all these eidos were as if carried away in a stream of time, instantly turning any present into the past - and in memory they seemed to be stopped, detained, retained, preserved.

${ }^{11}$ Флоренский П. А. Столп и утверждение истины. (Том 1, часть 1. Том 1, часть 2). М.: Правда, 1990. С. 193.

12 Флоренский П. А. Столп и утверждение истины. (Том 1, часть 1. Том 1, часть 2). М.: Правда, 1990. С. 197.

${ }^{13}$ Флоренский П. А. Столп и утверждение истины. (Том 1, часть 1. Том 1, часть 2). М.: Правда, 1990. С. 200. 
No magic is required to go beyond the bounds of consciousness, into the "astral", into the "rabbit hole" of the labyrinths of the subconscious, to which esoteric and pseudo-sci-fi "spiritual" practices are prone to invoke, bring the past or the distant into the "now", in the proximity of presence - we do this every moment of our life. Any simple logical operation involves mindfulness: moving from a subject to a predicate, we inevitably keep the subject in our memory, otherwise the predicate as if "sags" - because we already forgot the subject to which it belongs! When building a syllogism, the same thing happens: we do not create a syllogism, if, fixing the last premise, we forgot the first. Moreover, any act of sensory perception without compilation in memory is glued to individual reactions of our senses to various stimuli that are not correlated in a memorable unity.

\section{CONCLUSIONS}

Thus, memory collects and conditions all the various acts of our perception, thinking and cognition in their whole certainty. In this case, memory is the basis of any imagination, any imagination, any creativity: memory as an activity of the soul is mental creativity, while it is emphasized that our knowledge, precisely because of its rootedness in memory, initially does not refer to the temporary, but to the Eternal. Memory is a creative force capable of temporarily psychologically "corruptible" presentation converted into a mystical revelation through the retention and preservation, seen in time - forever. Simply put, memory - Communication link between a person of increments to the Eternal, and God, who is this eternity: "Therefore, indeed, the memory - this is the idea of excellence, the very idea in its purest and fundamental importance" 14 . The main motive in harmony with the ideas of Heidegger and Florensky is that memory creates, equips, forms an internal order and preserves thinking. Understood in the broadest possible sense, thinking is always mindfulness, and vice versa. Thinking, as was said at the beginning, is always the thinking of being. We do not determine the beginning and way of thinking, we enter into it.

But thinking, being rooted in being, nevertheless, inevitably gives in to it, retreats, takes flight. Why? Yes, because the powerful, innumerable variety of things and the amazing universality of being, this being of the one immeasurably exceeds, prevails, dominates thinking. We are in no way given the beginning and end of being, its initial, main secrets, with all its mysterious power we are weighed, tormented, tormented - and yet doomed to be turned on it. Yes, thinking - is always thinking of being, called for it has always been

${ }^{14}$ Флоренский П. А. Столп и утверждение истины. (Том 1, часть 1. Том 1, часть 2). М.: Правда, 1990. С. 203. 
and will be "not-yet" because the existence of infinitely stronger and deeper than any thinking appeals to it. Thinking and being are identical - identical on proportionality, but not identical in their original power. Before the multiple unity of being, thought is doomed to collapse, decay, oblivion. And, trying to overcome this oblivion, trying to cross the gap between the absolute and the individual, a person truly torments himself, suffers, dooms himself to the misfortune of consciousness. The all-conquering force of time, through which being itself reveals itself to us, carries away thinking, tears it from the roots and drags it along - there, into decay, into decay, into oblivion. This is precisely how the non-classical philosophical tradition arises - in the desperate refusal of the mind to embrace those historical and temporary cataclysms that fall upon the mind. Thought literally "sinks" in the waves of the time of being. Retreat, running away, despair, powerlessness of thought this is the theme of the philosophy of existentialism, which sees the fate of thought in accepting and experiencing this despair. Thought, unable to grasp the unity, order and harmony of being, makes the necessary conclusion about its absurdity. That is why the existential and in Heidegger's philosophy is so dark and frightening - because the most intense experience falling on the shoulders of his weight being is far outside the "comfort zone" of human existence. Alas, the forgetfulness of being, sin, evil, decay, collapse are not substantial, they do not have their own nature, but they are an inevitable, inseparable way of our presence in the world, because they are where we run, burdened by our own essence.

And that is precisely why memory is not just a "fundamental property", a "determining principle" of thinking. It is the only chance of thinking to resist the inevitable decay in front of the face of being, given for the thought addressed to us. Memory is a connecting and saving shield of thinking, a barrier standing in the way of an all-consuming time of being. In remembering, in tense retention of memory, we gain the ability to stay in our standing-in front of being, to stay almost "on an equal footing", at least without retreating into oblivion.

We were looking for the basis of the consonance of thought with being. It is necessary to identify what is capable of rhythmizing and harmonizing thinking- about. Thought only then retains its essence when it is in harmony, in harmony, in proportion to the data for thought. That is - for thinking, some symmetry, equal rights, balance between the thinker and we are merged is necessary, otherwise, again, thought will fall apart into thoughtlessness under the exorbitant weight of the given for thought. Such a "fair" balance and proportionality is found in the memory. Strictly speaking, it is memory that can recreate, grow, and conceive of being. And he does this in any of our human deeds. 
For example, we need to play a certain melody on some musical instrument. That is, the melody already exists, it is written, it is already being. And the tool also belongs to the realm of being, it is created. What remains for us, what falls to us in this case? To begin with, we recall the harmonious sequence of the melody, that is, we acquire its categorical structure, form (tempo, rhythm, duration) and content (order and consecutive arrangement of sounds). But we still need to remember how the melody should be performed on this musical instrument. And we remember (we regain it!), What actions are necessary to extract a particular sound, we recall from the memory the technique required for performance. Next, we need to remember what the melody sounds like - what it was created for, what experience, event, thought, phenomenon it announces. That is, we recall the mood of the melody. Then all dynamic and empathic nuances of the performance are recalled - melismas, amplification or tone-down, sound intensity, in other words, the character of the melody is created by memory.

And it turns out that in the simple reproduction of a melody (perhaps simple and unpretentious!), Memory creates a new, previously unprecedented, region of existence, creatively reflecting and developing an existing one. And what is most surprising is that all the creative work of memory that we painted for so long takes place not as a chain of mental acts, but instantly, timelessly, often - at the moment of performing the melody itself, holding together a huge number of these acts.

The unifying, protective and creative power of memory also manifests itself to us in the process of obtaining a philosophical education, when you read the primary sources you have a feeling that you are not so much learning new things - how much you remember what was originally known to you. Thinking therefore not to produce chimeras, and thinks being, because it is not of Thinking from itself some chords and ties of reality, but sees them in it, picks, listens, remembers reality.

The contours of the universal interconnectedness of being emerge through a chaotic pile of things and phenomena when we are able to catch, hold and remember, hold in memory the rhythm and melody of the consciousness of thinking and being.

\section{SUMMARY}

The article compares M. Heidegger and P. Florensky's approaches to memory understanding. Despite the fundamental difference of philosophical traditions, the author formulates the moments in which these thinking strategies coincide. This coincidence is as follows: in both cases, memory serves as a universal, integral foundation not only for the human psyche - for the human being as a whole. Attention is drawn to the ability of memory to 
maintain humanity in its entirety. Such integrity is understood as allowing one to preserve man, both as an entity and as history. In such coincidences of various thinking strategies, the author sees the possibility of formulating universal judgments about essential philosophical problems, since here one can trace the existence of some universal ontological foundation. Therefore, the comparison of different philosophical paradigms, based on the criteria of universal ontological parameters of the subject, is considered constructive and necessary by the author.

\section{REFERENCES}

1. Гальцева Р.А. Мысль как воля и представление (Утопия и идеология в философском сознании П.А. Флоренского). П.А. Флоренский: pro et contra / Сост., вступ. ст., примеч. и библиогр. К.Г. Исупов. СПб.: РХГИ, 1996. С. 559-605.

2. Флоренский П.А. Столп и утверждение истины. (Том 1, часть 1. Том 1, часть 2). М.: Правда, 1990. 352 с.

3. Фрагменты ранних греческих философов. Ч. 1. М.: Наука, 1989. $576 \mathrm{c}$.

4. Heidegger M. What is called thinking? Ed. J. Glenn Gray. Harper Perennial, 1976. 272 p.

Information about the author: Stepan Vozniak,

Candidate of Sciences (Philosophy), Associate Professor at the Department of Philosophy, Sociology and Religious Studies, Faculty of Philosophy, Vasyl Stefanyk Precarpathian National University 57, V.Chornovola str., Ivano-Frankivsk, 76015, Ukraine ORCID: https://orcid.org/0000-0003-2268-5736 